\title{
Remaja Perempuan yang Menikah melalui Perjodohan: Studi Fenomenologis tentang Penyesuaian Diri
}

\author{
Yusandi Rezki Fadhli
}

Fakultas Pendidikan Psikologi, Universitas Airlangga, Indonesia

\begin{tabular}{l}
\hline Info Artikel \\
\hline Sejarah Artikel: \\
Diterima \\
I4 Februari 2020 \\
Direview \\
24 Februari 2020 \\
Disetujui \\
28 September 2020 \\
Dipublikasikan \\
28 September 2020 \\
\hline Keywords: \\
Arranged marriages, \\
Late adolescence, \\
Self adjustment.
\end{tabular}

\begin{abstract}
Abstrak
Objektif: Perjodohan (arranged marriages) adalah suatu pernikahan yang diatur oleh orang tua atau kerabat dekat untuk pasangan, dan biasanya dilakukan pada perempuan remaja akhir yang nantinya akan memerlukan banyak penyesuaian setelah menikah. Tujuan dari penelitian ini untuk mengidentifikasi dan mendesripsikan secara utuh gambaran penyesuaian diri yang dialami oleh perempuan yang menikah di usia remaja akhir khususnya individu yang dijodohkan dengan calon suaminya.
\end{abstract}

Metode: Subjek dalam penelitian ini adalah 2 porang perempuan yang menikah pada usia remaja akhir melalui proses perjodohan. Tekinik pengambilan sampel dalam penelitian in adalah teknik purposive sampling. Metode yang digunakan dalam penelitian ini adalah pendekatan kualitatif dengan metode fenomenologis yang dilakukan melalui wawancara langsung dengan subjek.

Temuan: Hasil penelitian ini menunjukkan bahwa subjek memiliki penyesuaian diri baik terhadap pernikahan yang dijalani meskipun pernikahan tersebut merupakan pilihan orangtua dan bukan keinginan sendiri (perjodohan).

Kesimpulan: Penelitian ini dapat bermanfat bagi subjek dan pembaca untuk mengevaluasi pernikahan yang mereka jalani.

\section{Girls married through matchmaking: A phenomenological study} of self adaptation

Objectives: Arrangements (arranged marriages) are marriages arranged by parents or close relatives for the spouse, and are usually performed on late adolescent girls who will require a lot of adjustments after marriage. The purpose of this study is to identify and fully describe the picture of adjustment experienced by women who are married in their late teens, especially individuals who are mated with their prospective husband.

Method: Subjects in this study were 2 women who married in their late teens through a matchmaking process. The sampling technique in this study was purposive sampling technique. The method used in this research is a qualitative approach with phenomenological methods carried out through direct interviews with the subject.

Findings: The results of this study indicate that the subject has a good adjustment to the marriage that is undertaken even though the marriage is a choice of parents and not his own desire (matchmaking).

Conclusions: This research can be useful for the subject and the reader to evaluate the marriage they are having.

\footnotetext{
*Alamat korespondensi:

Universitas Airlangga Jakarta

Yusandi.rezki.fadhli-2016@psikologi.unair.ac.id
} 


\section{Pendahuluan}

Bagi mayoritas masyarakat Indonesia, sebelum memutuskan untuk menikah biasanya harus melalui tahaptahapan yang menjadi prasyarat bagi pasangan tersebut. Tahapan tersebut diataranya adalah masa perkenalan atau dating kemudian setelah masa ini dirasa cocok, maka mereka akan melalui tahapan berikut yaitu meminang. Peminangan (courtship) adalah kelanjutan dari masa perkenalan dan masa berkencan (dating). Selanjutnya, setelah perkenalan secara formal melalui peminangan tadi, maka dilanjutkan dengan melaksanakan pertunangan (mate-selection) sebelum akhirnya mereka memutuskan untuk melaksanakan pernikahan (Kertamuda, 2009). Menurut (Ardhianita \& Andayani, 2005), menikah merupakan momen yang penting dalam siklus kehidupan manusia. Pernikahan adalah suatu ikatan janji setia antara suami dan istri yang di dalamnya terdapat suatu tanggung jawab dari kedua belah pihak. (Bahana, 2015) juga mendefinisikan pernikahan sebagai suatu ikatan antara pria dan wanita yang permanen, ditentukan oleh kebudayaan dengan tujuan mendapatkan kebahagiaan. Sedangkan menurut Undang-Undang Nomor I Tahun 1974 Pasal I menjelaskan bahwa pernikahan adalah ikatan lahir batin antara pria dan wanita sebagai suami istri dengan tujuan membentuk keluarga atau rumah tangga yang bahagia dan kekal berdasarkan Ketuhanan Yang Maha Esa. (Afrida \& Andromeda, 2017) mengemukakan bahwa Menjalin hubungan pasangan suami isteri tentu memerlukan kesiapan yang matang, kesiapan fisik dan kesiapan mental, serta ada pula ketentuan usia dalam menikah. Selain itu serangkaian persyaratan yang harus di penuhi dalam pernikahan juga haruslah matang, terutama pada usia calon mempelai yang akan menikah. Pada pasal 2 berbunyi bahwa pernikahan dinyatakan sah apabila dilakukan menurut hukum masing-masing agama dan kepercayaan, serta tiap-tiap pernikahan dicatat menurut peraturan perundang-undangan yang berlaku (Mafaza, 2019).

Wibisana (2016) menyebutkan bahwa dalam menikah atau proses khitbah ada dua jenis pernikahan, yaitu memilih pasangan atas dasar kemauan sendiri dengan alasan cinta dan pernikahan yang dilakukan atas dasar kemauan keluarga atau kerabat dengan proses perkenalan yang telah diatur atau lebih dikenal dengan perjodohan. Pada masa lalu kita mengenal cerita tentang Siti Nurbaya sebagai suatu bentuk gambaran perjodohan di masa lalu yang umum dilakukan. Namun, sekarang mungkin masyarakat kita akan mencibir apabila ada orangtua yang menjodohkan anak-anaknya karena saat ini tren telah berubah. Muda-mudi jaman sekarang pada umumnya berpacaran sebelum memasuki jenjang pernikahan. Namun, pada abad modern ini, fenomena menikah melalui perjodohan masih banyak dijumpai di masyarakat yang meliputi beberapa daerah atau suku tertentu di Indonesia. Dalam pernikahan melalui perjodohan, pihak orangtua atau kerabat dekat telah mengatur untuk sang pasangan dan biasanya dilakukan pada wanita ( Habibi, 20I5). Perjodohan sudah dikenal oleh semua orang terutama umat islam. Banyak orangtua pada zaman dahulu hingga sekarang yang masih mencarikan jodoh atau suami untuk anak perempuannya (Takariawan, 2005). Perjodohan adalah suatu proses perencanaan menjalin suatu keluarga oleh wali yang bersifat lebih mengikat, dan lebih sering dilakukan tanpa sepengetahuan anak yang dijodohkan. Selain dengan perjodohan, pernikahan juga dapat dilakukan dengan proses ta'aruf, yaitu suatu proses perkenalan antara pria dan wanita dengan tujuan untuk menetapkan diri sebelum melangkah ke jenjang pernikahan sesuai dengan aturan Islam. Proses tersebut tidak disertai dengan pacaran, sehingga hanya saling mengenal dengan batas waktu tertentu dan terkadang disertai oleh istikharah atau meminta petunjuk kepada Allah (Mafaza, 2019).

Pernikahan melalui perjodohan memungkinkan penyesuaian terhadap pasangan dilakukan pada saat pasangan sudah menikah. Hal inilah yang membuat menikah melalui perjodohan memiliki tantangan tersendiri utamanya bagi pihak wanita di era modern saat ini. Mempelai wanita harus menghadapi kenyataan bahwa dia akan menjalani kehidupan rumah tangganya bersama orang yang bisa jadi belum dikenal sama sekali sebelumnya. Kondisi yang tidak mudah ini menyebabkan munculnya kekhawatiran tersendiri pada beberapa individu sehingga memicu beberapa kejadian yang memprihatinkan salah satunya seperti yang telah dialami seorang gadis yang berumur 15 tahun yang meminum pestisida setelah mengetahui rencana orangtuanya yang akan menjodohkan dirinya. Kasus tersebut terjadi di Jawa Timur, dusun Tegalan, desa Sidonganti, Kecamatan Kerek, Kabupaten Tuban (Kompas, 12 desember 20II). Kemudian sulitnya mencapai penyesuaian pernikahan melalui perjodohan didukung oleh hasil penelitian Habibi tahun 2015 yang berjudul "Kepuasan Pernikahan Pada Wanita Yang Dijodohkan; Wanita yang Dijodohkan Oleh Orang Tua”. Salah satu subjek dari penelitian tersebut yang berinisial SL mengungkapkan bahwa ia merasa kesulitan untuk dapat berkomunikasi dengan baik pada pasangannya dikarenakan sifat pasangan yang memiliki temperamen tinggi, hal ini menyebabkan SL lebih memilih untuk memendam saja mengenai apa yang ia pikirkan dan rasakan, SL juga merasa bahwa suaminya tidak dekat dengan keluarga dan teman-temannya, dan jarang terlibat membantu pekerjaan rumah atau pun menjaga anak dan hal-hal tersebut membuat SL merasa kecewa dan tidak puas terhadap pernikahannya. 
Tantangan menikah melalui perjodohan semakin bertambah bila pernikahan tersebut terjadi di usia remaja akhir, usia dimana pihak wanita masih belum dapat dikatakan stabil kondisi emosinya, masih ingin menikmati masa-masa bergaul dengan teman sebayanya serta sedang bersemangat menuntut ilmu (Habibi, 20I5). Menurut (Hurlock, 20II) remaja yang menikah di usia muda dengan rentang usia belasan tahun atau awal usia dua puluhan cenderung lebih sulit dalam menyesuaikan diri. Hal ini dikarenakan kesiapan mental pada awal pernikahan sangat dibutuhkan, agar mampu mengatasi ketegangan emosional yang muncul. Penyesuaian diri bagi seorang remaja yang sudah menikah diantaranya yaitu hubungan interpersonal dengan teman sebaya kurang intensif, menjaga tanggung jawab perkuliahan seperti kegiatan organisasi, kerja kelompok, dan menjadi ibu. Tanggung jawab tersebut akan semakin bertambah karena harus mengasuh anak. Ketika sudah memiliki anak akan mengalami peningkatan tuntutan untuk lebih mampu dalam menjalankan perannya sebagai istri, ibu dan pelajar. Kematangan usia individu saat menikah merupakan aspek yang penting karena dalam usia yang matang, pasangan dapat beradaptasi terhadap konflik atau masalah perkawinannya, mereka memiliki kemampuan untuk bangkit berusaha berkembang menjadi individu yang lebih kuat, dan lebih menghargai perkawinannya. Manakala pasangan merasa berhasil mengatasi permasalahannya maka mereka akan dapat merasakan kebahagiaan perkawinan, suami istri mampu menampilkan performa yang lebih baik untuk mempertahankan keharmonisan rumah tangganya (Susatya, 2016).

Penelitian ini dipilih penulis untuk mengetahui bagaimana seorang perempuan yang menikah di usia relatif muda melalui proses perjodohan menyesuaikan diri terhadap kehidupan pernikahannya. Kemudian, peneliti juga mendapatkan gambaran bagaimana seorang perempuan tersebut menghadapi konflik terkait tanggung jawabnya sebagai seorang istri dan seorang ibu. Topik penyesuain diri memang sudah banyak dibahas sebelumnya namun kebanyakan kasus yang telah diteliti adalah individu yang menikah di usia dini atau dibawah 17 tahun (sangat dini), dimana kebanyakan alasan pernikahan tersebut adalah karena ingin meringankan beban ekonomi keluarga atau karena married by accident (hamil sebelum menikah), lebih lanjut pernikahan dini tersebut juga umumnya terjadi di kota kecil dan pedesaan. Penulis memiliki alasan yang cukup mengenai pengambilan topik penyesuaian ini, berbeda dengan penelitian-penelitian sebelumnya pada kasus kali ini subjek dinikahkan bukan untuk meringankan beban orang tua atau alasan ekonomi. Subjek menikah di tahapan usia remaja akhir dimana memang sudah pada tahap subjek belajar mengenal lawan jenis namun secara kesiapan mental belum memiliki bekal yang cukup mengenai keterampilan menjalani hidup berumah tangga. Subjek juga melakukan banyak sekali penyesuaian diri terhadap berbagai konteks, antaranya terhadap pasangan, peran sebagai istri, peran sebagai ibu.

Pada penelitian sebelumnya mengenai penyesuaian diri pada perempuan yang menikah di usia dini, terdapat beberapa faktor yang mendukung penyesuaian diri seseorang antara lain dukungan sosial, kemampuan interpersonal, tingkat pendidikan dan kematangan pribadi. Sedangkan faktor yang menghambat antara lain pola asuh orang tua yang permisif, tinggal bersama keluarga suami saat belum memiliki kematangan emosi serta persepsi masyarakat terhadap pernikahan (Fatayati, 2016). Pada penelitian yang dilakukan (Habibi, 2015) mengemukakan bahwa subjek merasa tidak puas dengan pernikahannya dan mengalami penyesuaian yang kurang karena terpaksa menerima perjodohan yag dilakukan oleh orangtuanya. Selain itu yang menjadi penyebab ketidakpuasan pernikahan subjek karena tidak adanya komunikasi dua arah yang baik dan tidak adanya upaya dari pasangan subjek untuk memperbaiki hubungan. Masalah tersebut diperparah lagi dengan masuknya campur tangan mertua subjek yang memegang kendali dalam keuangan rumah tangga mereka.

Berdasarkan data-data yang telah diperoleh maka penelitian ini dilakukan untuk mengetahui tingkat penyesuaian diri pelaku pernikahan dengan melalui perjodohan. Keunikan pembahasan topik penelitian yang dipilih oleh penulis adalah penentuan partisipan yang berada di usia remaja akhir, dimana orang tua subjek tidak mengalami permasalahan ekonomi, dari keluarga yang pendidikannya menengah ke atas, subjek adalah murid berprestasi di sekolahnya pada saat itu, tinggal di kota besar dan dilakukan melalui proses perjodohan. Penelitian ini bertujuan untuk mengidentifikasi, mendesripsikan secara utuh gambaran penyesuaian diri yang dialami oleh perempuan yang menikah di usia remaja akhir melalui proses perjodohan, serta menguraikan faktor apa saja yang mendukung dan menghambat individu dalam melakukan penyesuaian diri. Penelitian ini juga bertujuan untuk memberikan informasi kepada masyarakat bahwa tidak semua pernikahan yang melalui proses perjodohan akan mengalami kegagalan seperti stigma yang sudah terbentuk di masyarakat. Selain itu penelitian ini bisa menjadi referensi untuk pasangan yang menikah dengan proses perjodohan agar hubungan pernikahan bisa bertahan dengan memperhatikan komunikasi-komunikasi yang perlu diterapkan dalam hubungan. 


\section{Metode}

Penelitian ini dilakukan menggunakan metode kualitatif dengan pendekatan fenomenologis. Studi fenomenologis mendeskripsikan pemaknaan umum dari sejumlah individu terhadap berbagai pengalaman individu tersebut, dan biasanya difokuskan untuk mendeskripsikan apa yang sama dari pengalaman individu (Cresswell, 2015). Dalam pendekatan fenomenologi hal yang diburu adalah esensi dari fenomena yang terjadi. Tujuan utama dari studi fenomenologis untuk mereduksi pengalaman individu yang khas dengan mengidentifikasi fenomena yang terjadi dalam konteks ini penyesuaian diri pada remaja akhir perempuan yang menikah melalui perjodohan. Peneliti menggali data dari setiap individu mengenai pengalaman kemudian dikumpulkan dan dikembangkan menjadi sebuah deskripsi. Deskripsi ini terdiri dari apa yang dialami oleh individu dan bagaimana individu tersebut mengalami (Cresswell, 20I5).

Variabel dalam penelitian ini ialah penyesuaian diri dan perjodohan. Analisis data yang digunakan dalam penelitian ini adalah anallisis deskriptif kualitatif, yaitu hanya melukiskan kenyataan yang berdasarkan keadaan yang diperoleh baik di lapangan maupun kepustakaan. Data-data yang diperoleh dalam penelitian ini nantinya berupa narasi, deskripsi, yang diperoleh dari hasil wawancara, observasi, dan dokumentasi sehingga analisis yang digunakan adalah analisis model Miles and Huberman, dimana dilakukan pada saat pengumpulan data berlangsung, dan setelah selesai pengumpulan data dalam periode tertentu. Peneliti melakukan wawancara terstruktur kepada informan, wawancara terstruktur yaitu wawancara yang dipandu menggunakan guide wawancara. Data yang lain didapatkan dengan observasi yang mana sebagai pengamatan atau pencatatan dengan sistematika fenomena-fenomena yang diselidiki, yang tidak terbatas pada pengamatan langsung dan tidak langsung. Setelah dianalisis terasa belum memuaskan maka peneliti akan melanjutkan pertanyaan lagi sampai tahap tertentu. Dalam analisis kualitatif dilakukan secara interaktif dan berlangsung terus menerus sampai tuntas sehingga datanya sudah jenuh. Penulisan analisis menggunakan deduktif induktif yaitu melakukan abstraksi dan melakukan rekaman fenomena-fenomena khusus yang dikelompokkan menjadi satu, kemudian teori yang dikembangkan nanti muncul dari sejumlah besar bukti yang terkumpul di lapangan dan saling berhubungan antara keduanya.

Subjek pada penelitian adalah perempuan yang menikah pada usia remaja akhir melalui proses perjodohan, dan berdomisili di Surabaya. Partisipan tersebut dipilih secara purposif (purposive sampling) berdasarkan kepada ciri-ciri yang sesuai dengan tujuan penelitian, yaitu menikah melalui proses perjodohan pada usia remaja akhir yaitu 17 hingga 19 tahun, telah menjalani pernikahan lebih dari 5 tahun, dan berdomisili di Kota Surabaya, Provinsi Jawa Timur. Akhirnya, terdapat dua perempuan yang memenuhi kriteria dan diwawancarai lebih lanjut oleh peneliti. Untuk mempermudah peneliti sajikan dalam bentuk tabel berikut.

Tabel I

Tabel Identitas Subjek

\begin{tabular}{ccccccc}
\hline No. & Inisial & Usia & Profesi & Jenis Kelamin & Pendidikan & Lama Menikah \\
\hline I & SAU & 29 Tahun & Dosen & Perempuan & S2 & II Tahun \\
2 & SWF & 28 Tahun & Dosen & Perempuan & S2 & 10 Tahun \\
\hline
\end{tabular}

Teknik analisis data yang digunakan peneliti merujuk pada Miles \& Huberman (Sugiyono, 20l4). Terdapat empat tahapan dalam analisis tersebut, yaitu tahap pengumpulan data, tahap reduksi data, tahap penyajian data, dan tahap penarikan kesimpulan. a) Pengumpulan Data, peneliti melakukan pengumpulan data dengan berawal pra penelitian melalui wawancara awal serta buku yang sesuai dengan peneliti butuhkan saat penelitian. b) Reduksi Data, peneliti memilah hasil wawancara dengan para informan sesuai dengan fakta dan kebutuhan penelitian, sehingga dapat di hasilkan data-data yang dibutuhkan peneliti. c) Penyajian Data, peneliti menggunakan pedoman wawancara serta dokumentasi sebagai sekumpulan informasi peneliti selama di lapangan. d) Penarikan Kesimpulan, dalam penarikan kesimpulan peneliti menyimpulkan hasil berdasarkan fakta yang ada di lapangan dan tujuan penelitian. Sehingga makna-makna yang muncul dapat sesuai dengan kebenarannya, kekokohannya, dan kecocokannya. 


\section{Hasil}

\section{Proses Perjodohan}

Pada awalnya, perkenalan SWF dan calon pasangan terjadi ketika berada dalam satu jama'ah pengajian yang diadakan oleh ayah SWF. Kemudian, calon pasangan pun menyatakan rasa sukanya melalui orangtua SWF. Setelah itu, orangtua SWF pun memutuskan untuk menikahkannya dengan calon pasangannya tersebut. Dengan pertimbangan sifat dari calon pasangan dan pandangan yang baik terhadap perjodohan, SWF pun menerima perjodohan tersebut. Sedangkan pada subjek SAU, ia langsung menyetujui permintaan sang Ayah untuk menikah dengan calon yang dipilihkan oleh ayah, namun calon tersebut sama sekali tidak pernah dikenal sebelumnya. Walaupun pada awalnya SAU merasa berat menerima perjodohan itu namun karena ingin berbakti kepada orang tua dan calon suami yang diperkenalkan oleh ayahnya adalah orang yang sabar dan baik agamanya maka SAU mau menerima.

\section{Masalah Penyesuaian Pernikahan}

Subjek SWF tidak mengalami kendala berarti dalam penyesuaian dengan pasangan. SWF dan suami mencoba untuk saling terbuka terhadap suami dan begitu pula sebaliknya. Melalui komunikasi secara langsung, SWF mencoba memahami apa yang disukai dan yang tidak disukai dari suami. SWF dan suami pun berusaha saling mengkomunikasikan perbedaan pendapat dan pandangan sehingga saling menghargai kemauan masing-masing. Sedangkan pada subjek SAU, ia mengaku mengalami kendala dalam penyesuaian dengan pasangan dikarenakan pola komunikasi dan perbedaan sifat. Di awal pernikahan subjek SAU yang merasa memiliki sifat romantis memiliki keinginan agar sang suami memperlakukan hal yang sama namun ternyata tidak bisa karena memang suami tidak terbiasa bersikap seperti itu. Walaupun kondisi tersebut cukup mengganggu hati subjek SAU namun lambat laun ia dapat memahami dan menerima bahkan bersyukur karena sang suami memiliki banyak sifat baik lainnya yang akhirnya menular pada diri subjek.

Dalam penyesuaian seksual, baik SWF dan SAU mengaku tidak mengalami kendala yang berarti. Subjek SWF dan suami hingga saat ini harus berbeda tempat tinggal karena tuntutan pekerjaan, subjek SWF di Surabaya dan suami di Bali. SWF pada dasarnya menginginkan untuk dapat tinggal bersama namun kondisi tidak memungkinkan. Walaupun tinggal terpisah, SWF memiliki prinsip agar waktu yang sedikit dapat berkualitas, hal tersebut salah satunya dengan sering bepergian bersama dengan suami saja sedangkan anak-anak dititipkan kepada sang ibu. Demikian pula dengan subjek SAU, ia merasa tidak memiliki kendala apa pun bahkan semakin hari terasa semakin menyenangkan. Dalam hal keuangan, subjek SWF tidak memiliki kendala apa pun, kondisi ekonomi rumah tangga pun dalam keadaan stabil bahkan ia merasa berlebih. Namun meskipun demikian, subjek SWF tetap mencoba untuk mencari pemasukan tambahan dengan berjualan VCD anak-anak saat kuliah. Lain halnya dengan subjek SAU, ia mengakui bahwa kondisi keuangan keluarga belum stabil, namun hal ini tidak pernah menjadi sumber konflik sejak awal menikah hingga sekarang. Subjek SAU dan suami justru saling menguatkan seperti membiayai kuliahnya saat SI saja ia berusaha mencari beasiswa prestasi, kemudian membuka toko busana muslimah online, serta berjualan makanan.

Dalam penyesuaian dengan keluarga masing-masing pasangan, berdasarkan hasil wawancara kepada SWF, ia merasa bahwa tidak ada kendala yang berarti terhadap keluarga suami. Namun, terkadang dalam kehidupan pernikahan mengalami pro dan kontra dalam mengambil keputusan yang melibatkan keluarga suami. Sedangkan dari hasil wawancara subjek SAU, ia tidak memungkiri adanya perbedaan pendapat namun hal tersebut bukan sesuatu yang besar dan dapat segera diselesaikan.

\section{Kriteria keberhasilan penyesuaian pernikahan}

Berdasarkan kriteria keberhasilan penyesuaian pernikahan, SWF dan SAU telah memenuhi keberhasilan kriteria-kriteria penyesuaian pernikahan tersebut. Kriteria-kriteria tersebut yaitu kebahagiaan suami istri, hubungan yang baik antara orangtua dan anak, penyesuaian yang baik pada anak, mampu menghadapi perbedaan pendapat dengan baik, kebersamaan, penyesuaian keuangan yang baik, serta penyesuaian keluarga yang baik dari pihak keluarga pasangan.

\section{Pembahasan}

Hasil penelitian menunjukkan bahwa berdasarkan kriteria-kriteria keberhasilan penyesuaian pernikahan nampak bahwa kedua subjek telah berhasil melakukan penyesuaian pernikahan dengan cukup baik meski 
mereka menikah di usia yang tergolong masih muda. Hasil penelitian ini sejalan dengan hasil penelitian yang dilakukan (Reyunix, 2017) bahwa terdapat hubungan positif antara penyesuaian diri terhadap perkawinan dengan kebahagiaan pada remaja putri yang melakukan pernikahan dini. Persamaan hasil penelitian ini dengan penelitian yang dilakukan oleh (Reyunix, 2017) bahwa adanya suatu penyesuaian pasangan dengan baik. Artinya adanya hubungan mutualisme (saling menguntungkan) antara pasangan suami istri untuk memberi dan menerima (menunaikan kewajiban dan menerima hak), serta adanya proses saling belajar antara dua individu untuk mengakomodasi kebutuhan, keinginan dan harapannya dengan kebutuhan, keinginan dan harapan dari pasangannya. Sedangkan yang membedakan penelitian ini dengan penelitian yang dilakukan oleh (Reyunix, 2017) adalah pada penelitian ini pengambilan data dilakukan dengan menggunakan analisis deskriptif kualitatif sedangkan yang pada penelitian yang dilakukan (Reyunix, 2017) menggunakan metode penelitian kuantitatif yaitu skala likert untuk mengukur sikap, pendapat dan persepsi seseorang atau kelompok orang tentang fenomena sosial

Penelitian ini juga sejalan dengan penelitian yang dilakukan oleh (Armaya, 2017) yang mengatakan bahwa setiap pasangan suami-istri baik itu yang melakukan pernikahan melalui proses perjodohan bahkan pacaran mereka sama-sama mengalami masa-masa sulit terkait penyesuaian diri pada awal pernikahan. Karena pada dasarnya konflik adalah sesuatu yang umum yang akan selalu dialami setiap orang. Namun pasangan tersebut mampu melewati dengan baik dan melakukan penyesuaian diri terhadap pernikahan mereka. Pada penelitian ini diperoleh data bahwa setiap subjek mengaku bahwa pernikahan mereka mengalami masa-masa sulit terkait keuangan, penyesuaian dalam mengatasi setiap konflik yang timbul dalam rumah tangga mereka. Sedangkan yang membedakan penelitian ini dengan penelitian yang dilakukan (Armaya, 20l7) ialah proses perjodohan dilakukan dengan jalan ta'aruf terlebih dahulu dibawah kader suatu lembaga. Sedangkan pada penelitian ini peneliti mengambil data melalui responden dengan kriteria tertentu seperti kedua pihak tidak mengalami kesulitan ekonomi, berprestasi di sekolah pada saat itu, dan tinggal di kota besar.

Penelitian lain yang sejalan dengan penelitian ini adalah penelitian yang dilakukan oleh (Tyas \& Herawati, 2017) mengemukakan bahwa kualitas pernikahan yang terdiri atas kebahagian dan kepuasan pernikahan termasuk dalam kategori penyesuaian pernikahan yang baik serta menikah pada usia muda. Sedangkan yang membedakan ialah pada penelitian yang dilakukan oleh (Tyas \& Herawati, 2017) ialah pernikahan subjek tidak dispesifikkan melalui proses perjodohan. Selain itu penelitian yang dilakukan (Latifatunnikmah \& Lestari, 2017) mengemukakan bahwa setiap pasangan membentuk komitmen untuk menghadapi tantangan pernikahan dan membuat kesepatakatan pernikahan. Hasil peneltian tersebut sesuai dengan hasil wawancara dengan subjek penelitian ini yang mengatakan subjek membuat kesepatakan dan komitmen Bersama pasangan serta membiasakan diri dengan apapun yang pasangan suka ataupun tidak suka sehingga dalam pernikahan mereka muncul rasa kepuasan dan penyesuaian pernikahan yang bagus. Namun, yang membedakan penelitian ini dengan penelitian yang dilakukan oleh (Latifatunnikmah \& Lestari, 2017) yaitu karakteristik subjek usia muda tidak dispesifikkan.

\section{Kesimpulan}

Pada umumnya masalah penyesuaian pernikahan terjadi ketika di awal-awal pernikahan terutama pada aspek penyesuaian pasangan serta aspek penyesuaian dengan keluarga pasangan, namun seiring berjalannya waktu masalah-masalah tersebut dapat terselesaikan dengan baik. Kedua subjek mengaku tidak memiliki kendala yang berarti dalam penyesuaian seksual maupun keuangan. Bagi subjek, walaupun kondisi keuangan rumah tangga belum stabil namun tidak menjadi sumber konflik dalam rumah tangga. Pada kriteria-kriteria keberhasilan penyesuaian pernikahan nampak bahwa aspek-aspek yang ada telah memenuhi kriteria bahwa kedua subjek telah berhasil melakukan penyesuaian pernikahan dengan cukup baik.

Berdasarkan Informasi dari hasil penelitian ini, maka penelitian ini bisa menjadi bahan dalam proses konseling keluarga dan perkawinan. Pernikahan yang dijalani dengan kemampuan komunikasi yang baik, rasa pengertian, serta komitmen kuat yang berlandaskan iman membantu pasangan dalam menghindari serta mengatasi masalah yang terjadi dalam pernikahan. Dilihat dari pengalaman proses perjodohan yang dialami kedua subjek, kedua subjek mengalami perjodohan dengan tipe Planned Type. Pada tipe ini orang tua merencanakan keseluruhan proses dan mempertimbangkan variabel dari segi keluarga dan komunitas. Dalam tipe ini individu yang dijodohkan memiliki interaksi yang rendah dan hanya melihat profil gambar atau bahkan tidak pernah bertemu dengan calon pasangan sampai hari pernikahan. Namun di sisi lain terdapat pula merupakan kombinasi dengan tipe Delegation Type. Pada tipe ini anak ikut andil dalam pemilihan pasangan. Sebagai calon yang akan menikah anak menentukan syarat tipe pasangan pada orang tua. Orang tua selanjutnya akan mencari pasangan sesuai dengan keinginan anak. Hal ini terutama nampak pada subjek dua yaitu $A$, dimana $A$ 
menginginkan pasangan yang sabar lalu kemudian orang tua dalam hal ini ayah menawarkan calon suami yang sabar kepada A.

\section{REFERENSI}

Afrida, S. N., \& Andromeda, A. (2017). Tipe Komitmen Perkawinan pada Pasangan yang Menikah Dini di Kabupaten Brebes. Intuisi : Jurnal Psikologi IImiah, 9(2), I29-I44.

Aini, A. K., \& Nuqul, F. L. (2019). Penyesuaian Diri Pada Pasangan Perjodohan di Kampung Madura. AlHikmah: Jurnal Agama Dan llmu Pengetahuan, 16(2), 78-88. https://doi.org// 0.25299/jaip.2019.voll6(2).3875

Ardhianita, I., \& Andayani, B. (2005). Kepuasan Pernikahan Ditinjau dari Berpacaran dan Tidak Berpacaran. Jurnal Psikologi, 32(2), I0I-III.

Armaya, S. (2017). Penyesuaian Diri Pasangan Suami Istri yang Menikah Melalui Proses Ta'aruf Dikalangan Kader PKS di Kota Binjai [Skripsi]. Tidak Diterbitkan. Universitas Islam Negeri Sumatera Utara.

Bahana, O. N. (20I5). Penyesuaian Pernikahan dengan Pasangan dan Makna Pernikahan pada Perempuan yang Dijodohkan [Skripsi]. Tidak Diterbitkan. Universitas Sanata Dharma.

Cresswell, J. W. (20I5). Penelitian Kualitatif dan Desain Riset. Pustaka Pelajar.

Fatayati, N. U. (2016). Penyesuian Diri dalam Pernikahan (Studi Kasus pada Istri yang Menikah Muda di Sumenep) [Skripsi]. Tidak Diterbitkan. UIN Sunan Kalijaga.

Habibi, U. R. (20I5). Kepuasan Pernikahan pada Wanita yang Dijodohkan. Psikoborneo, 3(2).

Hurlock, E. B. (20I I). Psikologi Perkembangan: Suatu Pendekatan Sepanjang Rentang Kehidupan. PT Erlangga.

Kertamuda, F. E. (2009). Konseling Pernikahan untuk Keluarga Indonesia. Salemba Empat.

Latifatunnikmah, L., \& Lestari, S. (2017). Komitmen Pernikahan pada Pasangan Suami Istri Bekerja. HUMANITAS: Indonesian Psychological Journal, 14(2), https://doi.org// 0.26555/humanitas.v| 4i2.5343

Mafaza, A. (2019). Dinamika Menikah saat Masih Kuliah: Studi Fenomenologis Pernikahan pada Mahasiswi yang Masih Aktif Kuliah [Skripsi]. Tidak Diterbitkan. Universitas Diponegoro.

Reyunix, S. (2017). Hubungan Penyesuaian Perkawinan dengan Kebahagiaan Pada Remaja (Desa Muara Badak Kabupaten Kutai Kartanegara). Psikoborneo, 5(2).

Sugiyono, S. (20I4). Metode Penelitian Pendidikan Pendekatan Kuantitatif, Kualitatif, dan R\&D. Alfabeta.

Susatya, J. (2016). Usaha-Usaha Pasangan Pernikahan Usia Dini dalam Menggapai Keharmonisan Keluarga. Magistra, XXIX (98), I4.

Takariawan, C. (2005). Di Jalan Dakwah Aku Menikah. Eraintermedia.

Tyas, P. F., \& Herawati, T. (2017). Kualitas Pernikahan dan Kesejahteraan Keluarga Menentukan Kualitas Lingkungan Pengasuhan Anak pada Pasangan yang Menikah Usia Muda. Jurnal Ilmu Keluarga \& Konsumen, IO(I), I-I2. https://doi.org/I0.24I56/jikk.2017.10.1.I

Wabisana, W (2016). Pernikahan dalam Islam. Jurnal Pendidikan Agama Islam-Ta'lim. Vol. I4, (2).

Zaidi, A. U., \& Shuraidy, M. (2002). Perceptions of Arranged Marriages by Young Pakistani Muslim Women Living in a Western Society. Journal of Comparative Family Studies, 33(4), 495-5I4. 